Article

\title{
The Potential Role of Hybrid Constructed Wetlands Treating University Wastewater-Experience from Northern Italy
}

\author{
Stevo Lavrnić ${ }^{1}$, Maribel Zapater Pereyra ${ }^{2}$, Sandra Cristino ${ }^{3, * \mathbb{C}}$, Domenico Cupido ${ }^{4}$, \\ Giovanni Lucchese ${ }^{4}\left(\mathbb{D}\right.$, Maria Rosaria Pascale ${ }^{3}$, Attilio Toscano ${ }^{1}\left(\mathbb{D}\right.$ and Maurizio Mancini ${ }^{4}$ \\ 1 Department of Agricultural and Food Sciences, Alma Mater Studiorum-University of Bologna, \\ Viale Fanin 50, 40127 Bologna, Italy; stevo.lavrnic@unibo.it (S.L.); attilio.toscano@unibo.it (A.T.) \\ 2 Independent Researcher, Gottfried-Keller-Str. 25, 81245 Munich, Germany; maribel_zapater@hotmail.com \\ 3 Department of Biological, Geological and Environmental Sciences, \\ Alma Mater Studiorum-University of Bologna, Via San Giacomo 12, 40126 Bologna, Italy; \\ mariarosaria.pascal2@unibo.it \\ 4 Department of Civil, Chemical, Environmental, and Materials Engineering, \\ Alma Mater Studiorum-University of Bologna, Via Umberto Terracini 28, 40131 Bologna, Italy; \\ domenicocupido1991@gmail.com (D.C.); giovannilucchesefrancesco@gmail.com (G.L.); \\ maurizio.mancini@unibo.it (M.M.) \\ * Correspondence: sandra.cristino@unibo.it
}

Received: 10 November 2020; Accepted: 14 December 2020; Published: 18 December 2020

check for updates

\begin{abstract}
University wastewater is a type of wastewater with higher pollutants load and flow rate variability than typical domestic wastewater. Constructed wetlands (CW) could be used for university wastewater treatment and consequently for wastewater reuse. A hybrid CW pilot plant, at the University of Bologna (Italy), was monitored to assess its potential to be used at the university. Its treatment performance was monitored for one year and public acceptance explored through a survey. The pilot plant had two treatment lines, (1) a vertical flow CW (VFCW) and a planted horizontal flow CW (HFCW), and (2) the same VFCW and an unplanted horizontal flow filter (HFF). The HFCW achieved higher removals than the HFF, but it was also found to be prone to higher water losses. However, both treatment lines met the Italian limits for discharge in natural water bodies and some of the limits for wastewater reuse in Italy and the EU. The VFCW alone was not able to meet the same limits, demonstrating the advantages of hybrid over single stage CWs. A positive attitude towards CWs and wastewater reuse was found among the survey participants. Therefore, hybrid CWs (planted and unplanted) are considered a feasible technology for application at universities.
\end{abstract}

Keywords: hybrid constructed wetland; public acceptance; wastewater reuse; wastewater treatment

\section{Introduction}

Climate change and human activities can have negative effects on the environment [1,2], and nature-based solutions (NBS), the low-cost and green technologies, are gaining more attention in the recent years due to their numerous benefits and the ability to mitigate some of these negative effects [2,3]. Constructed wetlands (CWs), a type of NBS, are engineered systems that use the processes occurring in natural wetlands in a more controlled environment in order to treat wastewater $[4,5]$. They can be considered as a good solution for small or medium communities [6,7] since they can be used for different types of wastewater $[8,9]$ and, therefore, might also be convenient for application in university campuses. Furthermore, CWs can also provide different ecosystem services such as 
aesthetic, educational and recreational benefits [10], convenient for the public spaces such as those of universities.

CWs can produce effluent suitable for reuse [11]; however, in order to use these systems as a part of wastewater reuse scheme on a larger scale and in countries with strict reuse limits, their performance has to be further improved. For example, it was reported that nitrogen removal in CWs might be low due to its limited capacity for denitrification and nitrification, and that removal of pathogens, one of the most important parameters for wastewater reuse, could often be unsatisfactory [2,12]. In addition, CWs can have large area requirements [8] and an increased water loss due to evapotranspiration that can have a considerable influence on their performance [13].

Single stage CWs cannot always reach strict water quality standards and therefore improvements (e.g., recirculation, artificial aeration and innovative media) or a combination of two or more CWs (hybrid systems) are commonly used, in order to enhance the removal efficiency, especially that of nitrogen [2,4]. For instance, Lavrnić and Mancini (2016) [12] showed that hybrid CWs in Southern Europe treating raw or primary treated municipal wastewater reached standards for the reuse more often than single stage systems.

Isolated buildings with green areas, such as university campuses, might need a decentralised wastewater treatment system, and, at the same time, they offer possibilities for wastewater reuse, for example, in irrigation. However, the quality of wastewater coming from the university buildings might be considerably different from domestic wastewater due to the absence of sources such as showers or clothes washing that might represent even $50 \%$ of the residential water consumption [14]. Moreover, that type of wastewater can be characterised by high inflow variability due to the low affluence of students and university staff during weekends, exam periods and holidays [15]. The presence of those factors can certainly be a challenge and, therefore, it is important to estimate the possibility for application of CWs in these conditions.

To achieve wider application of wastewater reuse practices, it is not enough to focus only on the water quality, but different aspects should be analysed together [16]. For example, public sites with CWs that were receiving primarily treated municipal wastewater were found to have a lower number of visitors than similar sites (with CWs or other natural treatment systems) receiving cleaner influent [17]. Moreover, since understanding CWs and the concept of treated wastewater reuse might not be very common among the general population, certain resistance to their application is usually encountered. In fact, public perception was reported to be one of the main problems preventing successful application of water reuse projects [18]. On the other hand, it was found that university students in Germany generally have positive attitudes towards water reuse, but at the same time they had many doubts about its quality [19].

Therefore, the objective of this research was to evaluate the potential of a hybrid CW to be used as a wastewater treatment technology at the University of Bologna (Northern Italy). For that purpose, two hybrid systems (with and without plants) were compared against each other and versus a single stage $\mathrm{CW}$ to understand their performance and effluent reuse capacity according to the current legislations. In addition, the attitude of the users towards CWs and wastewater reuse in their immediate surrounding was also explored.

\section{Materials and Methods}

\subsection{Experimental Set-Up}

The pilot plant used in this research (Figure 1a) was located at the School of Engineering and Architecture of the University of Bologna (Italy). It consisted of a septic tank (primary treatment), an inflow tank, a VFCW (secondary treatment) and two systems as tertiary treatment-a horizontal flow filter (HFF, not planted) and a horizontal flow CW (HFCW, planted) (Figure 1b). 


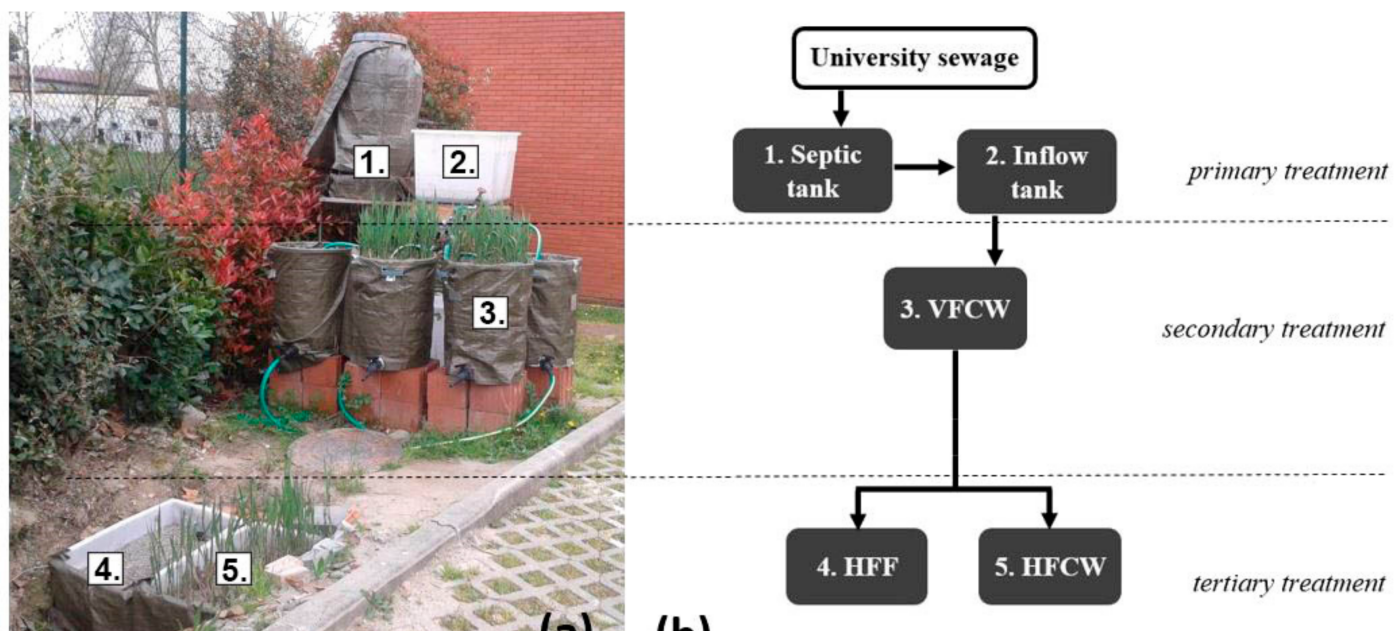

Figure 1. A photo of the pilot plant taken in March 2016 (a) and its schematic representation (b). VFCW-Vertical flow constructed wetland, HFF-Horizontal flow filter, HFCW-Horizontal flow constructed wetland.

The pilot plant was built in April 2015, and it treated wastewater coming from a university building (mostly blackwater) and an attached cafeteria. The VFCW and HFCW were planted with Phragmites australis at a density of 8 plants $\mathrm{m}^{-2}$ and filled with tap water for a period of 3 weeks to facilitate the root development. The start-up phase was 4 months long (June-October 2015), during which the systems were fed with a mixture of tap water and wastewater (in June) before being completely irrigated with only wastewater (July-September). This was a similar start-up phase as the one used by other studies [20-22].

The VFCW, which was used in a previous research to test the effect of plants and earthworms on wastewater treatment $[23,24]$, was filled with $12 \mathrm{~cm}$ of gravel at the bottom $(\varnothing 0.63-5 \mathrm{~cm})$, while the top $33 \mathrm{~cm}$ of substrate was sand (Ø 2-4 mm). Both HFF and HFCW had the dimensions of $69 \mathrm{~cm}$ (length), $41.5 \mathrm{~cm}$ (width) and $35 \mathrm{~cm}$ (depth). The main substrate used was sand (Ø 1-4 mm), but the effluent pipe was covered with gravel $(\varnothing 0.63-5 \mathrm{~cm})$ in order to facilitate the drainage.

The pilot plant was monitored for a period of one year (October 2015-October 2016). During the cold period of the year (October-April), the horizontal mesocosms received $6 \mathrm{~L}$ twice a week and the retention time was $\sim 4.5$ days. Conversely, during the warm period of the year (April-October), they received $6 \mathrm{~L}$ of water 3 times a week and the retention time was $\sim 3.75$ days. In addition, during the warmest period (the second half of July and the whole of September; operation of the pilot plant was suspended in August due to the university closure) the inflow was increased to $8 \mathrm{~L}$ three times a week, with the retention time unchanged, in order to prevent drying due to high evapotranspiration rate. Consequently, the hydraulic loading rate varied between 6 and $12 \mathrm{~mm} \mathrm{~d}^{-1}$.

\subsection{Wastewater Sampling and Analytical Methods}

Influents and effluents from the pilot plant were tested for different water quality parameters approximately every 3-4 weeks in the period of October 2015-October 2016 (Table 1). The analyses were performed following APHA (2005) [25] unless stated otherwise. Samples were analysed for $\mathrm{pH}$ by the electrometric method, chemical oxygen demand (COD) spectrophotometrically with a COD Vario cuvette kit (Aqualytic, Germany) and total suspended solids (TSS) by the gravimetric method. Total nitrogen (TN) and total phosphorus (TP) were analysed by digestion by the persulfate method followed by measurements of $\mathrm{NO}_{3}{ }^{-}-\mathrm{N}$ (ultraviolet spectrophotometric screening method) and $\mathrm{PO}_{4}{ }^{3-}-\mathrm{P}$ (vanadomolybdophosphoric acid colorimetric method), respectively. Finally, different ions such as nitrate $\left(\mathrm{NO}_{3}{ }^{-}\right)$, nitrite $\left(\mathrm{NO}_{2}{ }^{-}\right)$, phosphate $\left(\mathrm{PO}_{4}{ }^{3-}\right)$, chloride $\left(\mathrm{Cl}^{-}\right)$, bromide $\left(\mathrm{Br}^{-}\right)$, and sulphate $\left(\mathrm{SO}_{4}{ }^{2-}\right)$ were analysed by ion chromatography (DX-120, Dionex Corporation, CA, USA). 
Table 1. Performance of the pilot plant during the period October 2015-October 2016 (mean \pm st. error (sample size)).

\begin{tabular}{|c|c|c|c|c|c|c|c|c|}
\hline \multirow{2}{*}{$\begin{array}{c}\text { Parameter } \\
-\end{array}$} & \multirow{2}{*}{$\begin{array}{l}\text { Influent }^{\mathbf{a}} \\
\text { Value }\end{array}$} & \multicolumn{2}{|c|}{ VFCW Effluent ${ }^{b}$} & \multicolumn{2}{|c|}{ HFF Effluent } & \multicolumn{2}{|c|}{ HFCW Effluent } & \multirow{2}{*}{$\begin{array}{l}t \text { Test }^{\mathrm{e}} \\
p \text { Value }\end{array}$} \\
\hline & & Value & $\operatorname{RE}^{c}(\%)$ & Value & $\operatorname{RE}^{d}(\%)$ & Value & $\operatorname{RE}^{d}(\%)$ & \\
\hline $\mathrm{pH}$ & $6.65(7)$ & $7.18(12)$ & - & $7.27(10)$ & - & $6.95(9)$ & - & - \\
\hline $\operatorname{COD}\left(\mathrm{mg} \mathrm{L}^{-1}\right)$ & $886 \pm 74(13)$ & $263 \pm 32(15)$ & 70.4 & $151 \pm 29(15)$ & 42.5 & $157 \pm 30(14)$ & 40.1 & 0.953 \\
\hline $\operatorname{TSS}\left(\mathrm{mg} \mathrm{L}^{-1}\right)$ & $168 \pm 28(10)$ & $33 \pm 4(18)$ & 80.4 & $9 \pm 1(18)$ & 73.2 & $9 \pm 2(16)$ & 72.7 & 0.412 \\
\hline $\mathrm{TN}\left(\mathrm{mg} \mathrm{L}^{-1}\right)$ & $65 \pm 6(18)$ & $33 \pm 6(17)$ & 49.3 & $13 \pm 3(17)$ & 59.8 & $4 \pm 1(10)$ & 88.8 & 0.003 \\
\hline $\mathrm{NO}_{3}{ }^{-}-\mathrm{N}\left(\mathrm{mg} \mathrm{L}^{-1}\right)$ & $0.85 \pm 0.12(19)$ & $1.16 \pm 0.60(18)$ & - & $5.20 \pm 1.35(18)$ & - & $1.16 \pm 0.38(16)$ & - & 0.009 \\
\hline $\mathrm{NO}_{2}^{-}-\mathrm{N}\left(\mathrm{mg} \mathrm{L}^{-1}\right)$ & $0.03 \pm 0.03$ & $0.04 \pm 0.04(18)$ & - & $2.86 \pm 2.79(18)$ & - & $3.39 \pm 3.39(16)$ & - & 0.146 \\
\hline $\mathrm{TP}\left(\mathrm{mg} \mathrm{L}^{-1}\right)$ & $12.32 \pm 2.83(17)$ & $6.50 \pm 1.18$ & 47.3 & $2.48 \pm 0.70(17)$ & 61.8 & $0.75 \pm 0.19(14)$ & 88.5 & 0.008 \\
\hline $\mathrm{PO}_{4}{ }^{3-}-\mathrm{P}\left(\mathrm{mg} \mathrm{L}^{-1}\right)$ & $7.63 \pm 1.43(17)$ & $4.93 \pm 0.83(15)$ & 34.2 & $2.03 \pm 0.13(18)$ & 58.9 & $0.24 \pm 0.11(13)$ & 95.1 & $<0.001$ \\
\hline $\mathrm{Cl}^{-}\left(\mathrm{mg} \mathrm{L}^{-1}\right)$ & $78 \pm 5(19)$ & $77 \pm 7(18)$ & 0 & $74 \pm 7(18)$ & 5 & $70 \pm 15(15)$ & 9.7 & 0.396 \\
\hline $\mathrm{Br}^{-}\left(\mathrm{mg} \mathrm{L}^{-1}\right)$ & $2.56 \pm 0.35(19)$ & $1.72 \pm 0.26(18)$ & 33 & $1.87 \pm 0.24(18)$ & - & $1.93 \pm 0.24(16)$ & - & 0.373 \\
\hline $\mathrm{SO}_{4}{ }^{2-}\left(\mathrm{mg} \mathrm{L}^{-1}\right)$ & $69 \pm 5(19)$ & $66 \pm 9(18)$ & 3.5 & $75 \pm 8(18)$ & - & $59 \pm 19(15)$ & 10.2 & 0.031 \\
\hline $\begin{array}{c}\text { E. coli } \\
\left(\log _{10} \text { CFU } 100 \mathrm{~mL}^{-1}\right)\end{array}$ & $5.69 \pm 5.02(10)$ & $5.09 \pm 4.56(10)$ & 74.7 & $3.25 \pm 3.03(14)$ & 98.5 & $2.54 \pm 2.23(13)$ & 99.7 & 0.133 \\
\hline $\begin{array}{l}\text { Total coliforms } \\
\left(\log _{10} \text { CFU } 100 \mathrm{~mL}^{-1}\right)\end{array}$ & $5.85 \pm 5.81(4)$ & $4.81 \pm 4.40(10)$ & 90.7 & $3.84 \pm 3.63(11)$ & 89.3 & $3.63 \pm 3.46(10)$ & 93.5 & 0.081 \\
\hline $\begin{array}{c}\text { Enterococcus } \\
\left(\log _{10} \text { CFU } 100 \mathrm{~mL}^{-1}\right)\end{array}$ & $5.51 \pm 4.59(10)$ & $5.21 \pm 4.76(10)$ & 50.1 & $2.92 \pm 2.49(14)$ & 99.5 & $2.06 \pm 1.90(13)$ & 99.9 & 0.015 \\
\hline
\end{tabular}

a Sedimentation tank effluent; ${ }^{\mathrm{b}}$ The VFCW effluent was the influent for both HFF and HFCW; ${ }^{\mathrm{c}}$ Removal efficiency (RE) was calculated based on the influent (sedimentation tank effluent); ${ }^{\mathrm{d}}$ RE was calculated based on the VFCW effluent; ${ }^{\mathrm{e}} \mathrm{T}$ test $p$-values show the statistical comparison of the effluents HFF and HFCW. The conducted tests were $t$ test or Mann-Whitney U test. Bolded values show significant differences $(p<0.05)$. VFCW—Vertical flow constructed wetland, HFF-Horizontal flow filter, HFCW-Horizontal flow constructed wetland. 
The microbiological parameters (E. coli, Total coliforms and Enterococcus) were analysed by the membrane filter technique followed by incubation and enumeration using a Chromogenic Coliform Agar for E. coli and Total coliforms [26], and a Slanetz Bartley Agar for Enterococcus [27].

\subsection{Effect of Plants on Wastewater Treatment}

The effluent concentrations of the HFCW and the HFF were statistically compared ( $t$ test) in order to evaluate the contribution of plants to wastewater treatment during the whole experimental period. The data were first checked for normality and equal variance, and if the assumptions were not met, the values were $\log _{10}$ transformed. In the case when the assumptions could not be met even after the transformation, a Mann-Whitney U test was used. All the analyses were performed using SigmaPlot 13 software.

\subsection{Public Acceptance of CWs and Wastewater Reuse}

An online questionnaire was created to find out the attitude of the daily users of the building of the School of Engineering and Architecture towards CWs and a possible reuse of wastewater treated. The participants were asked seven questions about their opinion of the mentioned topic, apart from questions regarding their social structure (sex, age, level of education). Answers were given by using the scale 1-5, 1 being the most negative and 5 the most positive attitude. The contestants were mostly reached through the social network Facebook.

\section{Results and Discussion}

\subsection{Treatment and Reuse Potential}

Results of the pilot plant performance are given in Table 1. The primarily treated university wastewater (septic tank effluent) will be considered as "influent" for the purpose of this study. It can be seen that, even after the primary treatment, wastewater can be considered to be of high strength [28]. That was due to the fact that wastewater was coming mostly from university toilets and cafeteria, so the factors that usually dilute domestic wastewater (e.g., showers, washing machines) were not present.

The majority of pollutants were mostly removed in the VFCW, as discussed in more detail in Lavrnić et al. (2019) [24]. Similarly, Ávila et al. (2016) [29] and Zhai et al. (2016) [30] also found that majority of pollutants were mostly removed in the first stage of a hybrid CW (VFCW+HFCW). Such behaviour might be explained by first-order kinetics and the increased removal in the case of high influent concentrations [31].

The pollutants removal achieved by both lines (HFCW and HFF) of the pilot plant was high. For example, in both treatment lines, the COD decreased from 886 to $<158 \mathrm{mg} \mathrm{L}^{-1}$ and TSS from 168 to $9 \mathrm{mg} \mathrm{L}^{-1}$ (Table 1). Nutrients removal efficiencies were higher than $79 \%$ for both TN and TP. In addition, all three indicator pathogens were removed for more than $98 \%$, with E. coli decreasing for more than 2.3 and Enterococcus for more than $2.5 \log$ units (Table 1). These results are comparable or higher than those reported in Torrijos et al. (2016) [32] and Zhai et al. (2016) [30], although influents used in those studies (e.g., COD in the range 193-405 $\mathrm{mg} \mathrm{L}^{-1}$, TN in the range 53-57 $\mathrm{mg} \mathrm{L}^{-1}$ ) were of much lower strength than the one used in this manuscript. Therefore, the high removal achieved in this study can be attributed to a longer hydraulic retention time (HRT) ( $>4.5$ in this study vs. $<2.7$ days in Zhai et al. (2016)) or explained by the first-order kinetics where a high influent concentration results in a high removal efficiency [31]. Both systems were new (in operation for less than 2 years) as the hybrid CW reported here, and therefore no difference in the removal efficiencies can be attributed to the age of the system.

It should be noted that the removal efficiencies obtained during the one-year experimental period might change as the system ages, since it was suggested that some removal processes in CWs can vary with time [33]. For instance, adsorption processes were found to be responsible for TN removal at the beginning of the CW operation (approximately 5-24 months), while microbial processes gained advantage as operation time passed [34]. TP removal efficiency can also be reduced as the substrate's 
sorption capacity decreases over time [35]. In addition, certain processes are influenced by the presence of organic matter and since it tends to accumulate over time in CWs [36], it might cause a change in effluent concentrations over a longer experimental period.

To understand how the systems performed according to 3 legal thresholds-guidelines for discharge to natural water bodies (in Italy) and for wastewater reuse in Italy and European Union (EU). The standards for discharge to natural water bodies were not met by the VFCW effluent (COD and E. coli values were too high) but they were met by the HFF and HFCW effluents (Table 2) [37]. Therefore, the studied hybrid pilot plant could be used to treat university wastewater and the effluent could be discharged into surface water bodies.

Wastewater reuse in Italy does not distinguish different reuse types, but some exceptions are allowed when the treatment is done by a NBS (called "general reuse" in this study) and when the treated wastewater is intended to be reused in irrigation (called "irrigational reuse" in this study) [38]. The VFCW, HFF and HFCW produced effluents that had the values of COD and E. coli too high to meet both general and irrigational reuse (Table 2). In addition, the HFF also had a TP concentration $\left(2.48 \mathrm{mg} \mathrm{L}^{-1}\right)$ slightly above the threshold for general reuse $\left(2 \mathrm{mg} \mathrm{L}^{-1}\right)$ but met the limits for irrigational reuse $\left(10 \mathrm{mg} \mathrm{L}^{-1}\right)$ (Table 2). Hence, the effluent of both systems should be further treated if planned to be reused in Italy.

The EU regulations for water reuse in agricultural irrigation [39] were recently adopted by the EU (approved in May 2020, valid from June 2023). They are expected to represent a boost for this practice in the EU, and in particular in Italy, since they are more flexible than the current Italian guidelines. When the effluent concentrations are compared to the new EU limits, it can be seen that TSS removal was on the satisfactory level and its concentration was below the limits for all four reuse types (Table 2). E. coli removal by the hybrid system was not sufficient for reuse types A (e.g., root crops consumed raw and food crops where the edible portion is in direct contact with reclaimed water) and B (e.g., food crops consumed raw where the edible portion is not in direct contact with reclaimed water, all irrigation methods). However, both HFF and HFCW effluents are suitable for Type D (industrial, energy, and seeded crops), while HFCW effluent also satisfies limits for Type C (the same as type B, but allowing only drip irrigation) [39]. It is important to mention also that the VFCW alone would not be able to reach limits for any of the four reuse types due to the high E. coli concentration, emphasising the benefits of hybrid systems in comparison with single stage CWs.

In order to meet the Italian reuse limits or the reuse types A and B of the new EU guidelines (Table 2), an additional treatment step would be required. Ávila et al. (2013) [40] used a free water surface CW (FWSCW) as the additional treatment step after a hybrid CW (VFCW+HFCW), and reported that it did not considerably improve the system's performance. Wu et al. (2016) [41] concluded that, in general, HFCWs have a higher removal rates of pathogens than FWSCWs and therefore, adding another HFF or HFCW at the end of the studied treatment plant in Bologna would probably help to meet the reuse limits. Other solutions include a combination of the treatment line with an ultraviolet disinfection unit disinfection unit [42] or introduction of aeration in the horizontal system [41], both of which can increase removal of pathogens and probably help meeting the reuse limits [2]. Moreover, a combination of CWs with more intensive technologies such as up-flow anaerobic sludge blanket were also successfully used for wastewater treatment of smaller communities [43].

Regarding effluent water availability, the studied HFCW sometimes turned to a zero-discharge system during the summer months, probably due to the presence of plants and their transpiration processes. The HFF, on the other hand, was never found to be completely dry. Milani and Toscano (2013) [13] concluded that evapotranspiration rates for small-scale CWs can be much higher compared to natural wetlands with larger areas due to the clothesline and oasis effect. High water loss through evapotranspiration was also reported by Zapater-Pereyra et al. (2016) [44] for a rooftop wetland with a small depth $(9 \mathrm{~cm})$ and a large area $\left(306 \mathrm{~m}^{2}\right)$. Unfortunately, in the current study it was not possible to estimate the exact evapotranspiration losses. However, pronounced water loses probably occurred due to the small flow rate and scale of the pilot plant. Nevertheless, further tests on a bigger scale would be needed to test this hypothesis. 
Table 2. Comparison of the studied systems effluent with the standards for reuse and discharge to natural water bodies.

\begin{tabular}{|c|c|c|c|c|c|c|c|c|c|c|}
\hline \multirow{2}{*}{$\begin{array}{c}\text { Parameter } \\
-\end{array}$} & \multirow{2}{*}{$\begin{array}{c}\text { VFCW } \\
\text { Mean Value }\end{array}$} & \multirow{2}{*}{$\begin{array}{c}\text { HFF } \\
\text { Mean Value }\end{array}$} & \multirow{2}{*}{$\begin{array}{c}\text { HFCW } \\
\text { Mean Value }\end{array}$} & \multirow{2}{*}{$\begin{array}{c}\begin{array}{c}\text { Italy Discharge } \\
\text { Regulation } \\
{[37]}\end{array} \\
\text { Natural Water Bodies }\end{array}$} & \multicolumn{2}{|c|}{$\begin{array}{c}\text { Italy Reuse Regulation a } \\
\text { [38] }\end{array}$} & \multicolumn{4}{|c|}{$\begin{array}{l}\text { EU Regulation for Water Reuse }{ }^{\mathbf{b}} \\
\text { [39] }\end{array}$} \\
\hline & & & & & General & Irrigational & Type A & Type B & Type C & Type D \\
\hline $\mathrm{COD}\left(\mathrm{mg} \mathrm{L}^{-1}\right)$ & 263 & 151 & 157 & 160 & 100 & 100 & - & - & - & - \\
\hline TSS $\left(\mathrm{mg} \mathrm{L}^{-1}\right)$ & 33 & 9 & 9 & 80 & 10 & 10 & 10 & 35 & 35 & 35 \\
\hline $\mathrm{TN}\left(\mathrm{mg} \mathrm{L}^{-1}\right)$ & 33 & 13 & 4 & - & 15 & 35 & - & - & - & - \\
\hline $\mathrm{TP}\left(\mathrm{mg} \mathrm{L}^{-1}\right)$ & 7 & 2.48 & 0.75 & 10 & 2 & 10 & - & - & - & - \\
\hline E. coli $\left(\right.$ CFU $\left.100 \mathrm{~mL}^{-1}\right)$ & 123,400 & 1790 & 350 & $5000^{c}$ & 50 & 100 & 10 & 100 & 1000 & 10,000 \\
\hline
\end{tabular}

a The Italian guideline for reuse does not include different types of reuse, but it does allow some variations in their reuse limits when the technology used is a nature-based system (called "general reuse" in this study), and also when treated wastewater is intended to be used in irrigation (called "irrigational reuse" in this study); ${ }^{\text {b }}$ Type A-All food crops, including root crops consumed raw and food crops where the edible portion is in direct contact with reclaimed water; Type B, C-Food crops consumed raw where the edible portion is produced above ground and is not in direct contact with reclaimed water, Processed food crops, Non-food crops including crops to feed milk- or meat-producing animals, depending on the irrigation method (type B allows all irrigation methods, type C only drip irrigation); Type D-Industrial, energy, and seeded crops. ${ }^{\mathrm{C}}$ Maximal recommended value, the competent authority can decide the exact limit. 


\subsection{Hybrid CWs for Wastewater Reuse}

As previously stated, single stage CWs are not as effective as hybrid ones, and therefore, they normally have more difficulties to meet reuse limits [2,12]. For example, Herrera Melián et al. (2010) [45] concluded that a second stage of a hybrid CW (VFCW+HFCW) performed at least equally as the first one regarding disinfection performance and that together they represented a robust option for wastewater treatment and reuse. Similarly, Avila et al. (2013) [40]concluded that a second and even a third stage of a hybrid CW would probably prove crucial to achieve an effluent quality needed for reuse. Moreover, Zurita and White (2014) [11] treated university wastewater, with a similar strength to the one used in this study, and showed that, although the first stage of a hybrid CW had high removal efficiencies, at least two stages of treatment are needed to achieve the disinfection levels required for the reuse of treated wastewater for irrigation.

Similar results were obtained in the current study when treating university wastewater. Despite the fact that the VFCW did most of the treatment, it was not enough to reach either reuse or discharge limits (Table 1). Hence, for such a purpose, a hybrid system is more suitable and recommended.

However, legislations should be considered as the real bottleneck, since, in the case of flexible standards (i.e., the new EU regulation) any of the hybrid systems (VFCW+HFCW or VFCW+HFF) were able to meet the reuse standards, while in the case of strict reuse limits (i.e., Italian regulation), it is recommended to have an additional step (after the hybrid system) mainly to meet the pathogen limitations.

\subsection{Effect of Plants on Wastewater Treatment}

To understand the effect of plants, a planted CW (HFCW) and an unplanted filter (HFF) were tested as the second stage of the hybrid system for a period of 1 year. It should be noted that, although reaching steady state conditions in a CW might require between 1 and even 4 years [33,46], several CW studies were conducted during an experimental period similar to the one used in this study [46-48].

Along the whole experimental period, the HFCW showed to have significantly lower concentrations $(p<0.05)$ for several parameters (e.g., TN, TP, and Enterococcus) than the HFF (Table 1). Carballeira et al. (2016) [47] also reported that plants had a positive effect on the nutrient removal in horizontal systems that were monitored for 2.5 years. However, no significant difference was found $(p>0.05)$ in COD or TSS effluent concentrations between the HFCW and HFF in the present study (Table 1). That is in accordance with Ciria et al. (2005) [21] and Collison and Grismer (2015) [46], who did not find any difference in COD and TSS removal between planted and unplanted systems over an experimental period of 18 and 7 months, respectively. Although most of the oxygen introduced to the substrate by plants is used for respiration, usually some of it is lost to the rhizosphere, and hence is not sufficient for aerobic degradation [3]. It can be hypothesised that the amount of oxygen introduced to the HFCW substrate by the plants was not enough to foster aerobic degradation of organic matter that would increase COD and TSS removal beyond the level reached in the HFF, causing anaerobic pathways to be dominant for organic matter removal [49].

The observed differences in nutrient removal between HFF and HFCW (effluent concentration of TN: 13 vs. $4 \mathrm{mg} \mathrm{L}^{-1}$ and TP: 2.48 vs. $0.75 \mathrm{mg} \mathrm{L}^{-1}$, respectively) (Table 1) can be attributed to the presence of plants. They were reported to have an important role in the removal of nutrients $[9,47]$ due to the direct nutrient absorption, the action of the aerobic microorganisms located in their rhizosphere [50] or the provision of an additional source of carbon for denitrification processes due to plant decay [51].

Among the $\mathrm{Cl}^{-}, \mathrm{Br}^{-}$and $\mathrm{SO}_{4}{ }^{2-}$ ions, the presence of plants significantly increased the $\mathrm{SO}_{4}{ }^{2-}$ removal showing statistically significant differences $(p<0.05)$ (Table 1$)$ between the HFCW and the HFF. That is probably connected to the increased presence of different carbon sources from the plant litter that enabled $\mathrm{SO}_{4}{ }^{2-}$ reduction [52].

It is not clear if vegetation contributes to the removal of indicator bacteria [53]. For example, Wu et al. (2016) [41] stated that in the majority of cases, the presence of vegetation has a positive 
influence on the removal of indicator bacteria in HFCWs. Headley et al. (2013) [48] suggested, based on a 16-month long experimental period, that plants do not play a big role in that process since removal of pathogens mostly depends on physical parameters. Carballeira et al. (2016) [47] showed that there is often little or no significant difference in pathogens removal between planted and unplanted systems. In this study, the HFCW had a significantly lower effluent concentration of Enterococcus compared to the HFF (2.06 vs. $2.92 \log _{10}$ CFU $100 \mathrm{~mL}^{-1}$, respectively; Table 1), but the authors could not find any similar situation in the published literature. However, it has been indicated that the presence of plants can, although with a minor effect, improve pathogen removal [47] maybe due to the physical effects (changing the system hydraulics) or through biological ones (increased surface area availability at plant roots or root exudates) [41]. Therefore, it is hypothesised that E. coli and total coliforms removal was not affected by the presence of plants since it was more related to the physical properties (such as HRT that was the same in both hybrid systems), while the effect of plants was more expressed, and therefore visible, in the removal of Enterococcus. Further research is needed in this regard.

The results about the role of plants obtained by this study are based on a one-year long experimental period. Literature provides conflicting information about the effect that different CW's operation times can have on the role of the vegetation and on the treatment performance, and therefore, these results should be taken with certain caution. For instance, while some authors reported that the removal of organic matter in CWs can be taken stable over the years $[54,55]$ and that TN and TP removal after 10 years of operation were comparable to those recorded at the beginning [54], it was also suggested that CWs can experience important removal efficiency variations over their life time [33]. As they are aging, the HFF and HFCW might experience certain process shifts and removal rates changes, and it is not clear if and how the role of plants might vary during this time.

\subsection{Public Acceptance of CWs and Their Effluent Reuse}

The online questionnaire reached 76 participants and majority of them were male ( $59 \%$ vs. $41 \%$ of female) and students (91\% vs. $9 \%$ of different types of university employees). Moreover, out of the four age groups $(<29,30-49,50-64,>65$ years old), the majority of participants $(95 \%)$ was under 29 years of age. The results are given in Table 3.

Table 3. Online questionnaire and summary of the results obtained from 76 users.

\begin{tabular}{|c|c|c|c|c|c|}
\hline Do you know: & yes & no & & & \\
\hline - what constructed wetlands are? & $61 \%$ & $39 \%$ & & & \\
\hline $\begin{array}{l}\text { - that at the university there is a constructed wetland } \\
\text { pilot plant? }\end{array}$ & $34 \%$ & $66 \%$ & & & \\
\hline On a scale from 1 to $5 *$, how much do you agree with: & 1 & 2 & 3 & 4 & 5 \\
\hline - $\quad$ reusing treated wastewater for irrigation? & $1 \%$ & $5 \%$ & $7 \%$ & $28 \%$ & $59 \%$ \\
\hline $\begin{array}{l}\text { - treating university wastewater with the existing pilot } \\
\text { plant system? }\end{array}$ & $1 \%$ & $1 \%$ & $14 \%$ & $20 \%$ & $63 \%$ \\
\hline $\begin{array}{l}\text { - using the water from the constructed wetland system } \\
\text { to irrigate the university green areas? }\end{array}$ & $1 \%$ & $5 \%$ & $8 \%$ & $16 \%$ & $70 \%$ \\
\hline $\begin{array}{l}\text { - using treated wastewater for toilets flushing in the } \\
\text { university building? }\end{array}$ & $1 \%$ & $3 \%$ & $8 \%$ & $12 \%$ & $76 \%$ \\
\hline
\end{tabular}

* The scale range is from 1 (do not agree at all) to 5 (very much agree). 
Although $61 \%$ of the participants knew what CWs are, only $34 \%$ of them knew about the existence of the pilot plant at the School of Engineering and Architecture, University of Bologna (Italy). Moreover, the great majority of the interviewed users was in favour of treating wastewater with the pilot plant and reuse of its effluent for irrigation of green areas or toilet flushing. These results were unexpected as public approval for wastewater reuse is limited due to emotional discomfort [56]. Although the School of Engineering and Architecture offers different engineering studies that are not all connected to the environmental area, the high support might, due to similar interests, be a result of the big number of participants being from the environmental field. Also, the high educational level of people that filled the questionnaire could explain this behaviour, since it was reported to be connected with higher approval of wastewater reuse [18]. The additional factor might be the fact that the participants had somewhat direct contact with the CW systems.

The pilot plant was placed in the yard of the School of Engineering and Architecture, near the cafeteria and a green area where students would spend their breaks. Some authors of this manuscript were approached by students or staff while operating the pilot plant and were asked about the nature of their study and performance of the system. That clearly shows interest and suggests a positive attitude of the potential users towards the pilot plant, as also shown by the questionnaire results (Table 3). Ghermandi and Fichtman (2015) [17] found that a clear human involvement (e.g., through the installation of recreational facilities and educational displays) can increase interest of the general public. It suggests that a positive attitude of the participants could be maintained and increased by, for example, setting panels that would offer basic information about the system. The online questionnaire provided in this study can be considered a first step to involve the citizens, testing the compliance with wastewater treatment and reuse approach trough their feedback.

Although managers and the public are not always aware of the potential values of CWs [57], Ezeah et al. (2015) [58] reported a recent increase in public support for CWs as wastewater treatment systems due to the different benefits that they can provide. That can also explain the positive attitude of the questionnaire participants (Table 3). On the other hand, Everard et al. (2012) [59] did a survey with stakeholders associated with 16 integrated CWs (CWs that served not only for wastewater treatment, but also provided different ecosystems services) in Anne Valley catchment in South-Eastern Ireland. Although many interviewees focused on the economic benefits connected to their ability to treat wastewater, the majority of them recognised integrated CWs as socially beneficial resources that were contributing in different ways to the quality of life of the area. Moreover, it was recorded that some farmers that in the beginning had a negative opinion of CWs, accepted the idea and installed their own systems after seeing successful application at neighbouring farms [59]. That is in accordance with Rice et al. (2016) [18] who stated that people can have the initial negative opinion of the technologies they are not familiar with. Therefore, a negative or medium attitude towards the pilot plant in this questionnaire could be changed with time and different actions that would show the importance of the concept (e.g., information panels, guided visits).

\section{Conclusions}

The present research had the objective to assess the potential of hybrid CWs to be used in universities for wastewater treatment. The system included a septic tank, a VFCW as a secondary stage, and a HFCW (planted) and HFF (unplanted) as a tertiary stage. Both treatment lines were tested in parallel in order to determine which one is better according to the applicable reuse regulations.

The results showed that both treatment lines (VFCW+HFF and VFCW+HFCW) were able to treat wastewater to be discharged in natural water bodies. In addition, both treatment lines met the Italian reuse (general and irrigational) thresholds for TSS and TN but that was not the case for COD and E. coli. However, if the EU regulations are taken into consideration, both treatment lines are suitable for the reuse Type D (for industrial, energy and seeded crops) and, for instance, the effluent could be used to irrigate energy crops if universities use them for heat generation during winter. The hybrid VFCW+HFCW also satisfied the limits for the reuse Type C (e.g., for food crops consumed raw where 
the edible part is not in direct contact with reclaimed water) and it could even be used for irrigation of certain food crops (only with drip irrigation method) in experimental university gardens for instance.

It is worth noting that the hybrid systems had a higher pollutants removal than the VFCW alone, the later not being able to satisfy any of the reuse types mentioned or the limits for discharge to natural water bodies. On the other hand, the hybrid systems low pathogen removal can be further increased by the addition of other components such as another CW or UV lamp.

The presence of plants positively influenced the HFCW performance over the one-year study, especially for nutrient (TN and TP) and Enterococcus removal, compared to the HFF. For example, TN removal efficiency was $60 \%$ for the HFF and $89 \%$ for the HFCW. COD and TSS removals were independent of the presence of plants, and for both systems it was in the range $40-43 \%$ and $72-74 \%$, respectively. However, a longer experimental period might be required to confirm these findings.

Public attitude for wastewater treatment by CWs and reuse of their effluent, an important aspect that is not always considered, was found to be very positive among the participants, a result that could indicate an increased awareness for environmental issues among young and highly educated people.

Therefore, the hybrid CWs tested (both planted and unplanted) can be considered as a viable and environmentally friendly alternative for the treatment and reuse of wastewater coming from smaller communities or individual buildings like universities.

Author Contributions: Conceptualization, S.L., M.Z.P., S.C., M.M. and A.T.; Methodology, S.L., M.Z.P., S.C. and D.C.; Formal analysis, S.L.; Investigation, S.L., D.C., G.L., S.C., M.Z.P. and M.R.P.; Resources, M.M. and S.C.; Data curation, S.L.; Writing-original draft preparation, S.L., M.Z.P., S.C., D.C. and M.M.; Writing-review and editing, S.L., M.Z.P., S.C., D.C., G.L., M.R.P., M.M. and A.T.; Supervision, M.M. and S.C. All authors have read and agreed to the published version of the manuscript.

Funding: This research received no external funding.

Conflicts of Interest: The authors declare no conflict of interest.

\section{References}

1. Pavanelli, D.; Cavazza, C.; Lavrnić, S.; Toscano, A. The Long-Term Effects of Land Use and Climate Changes on the Hydro-Morphology of the Reno River Catchment (Northern Italy). Water 2019, 11, 1831. [CrossRef]

2. Nan, X.; Lavrnić, S.; Toscano, A. Potential of Constructed Wetland Treatment Systems for Agricultural Wastewater Reuse under the EU Framework. J. Environ. Manag. 2020, 275, 111219. [CrossRef] [PubMed]

3. Pap, S.; Šolević Knudsen, T.; Radonić, J.; Maletić, S.; Igić, S.M.; Turk Sekulić, M. Utilization of Fruit Processing Industry Waste as Green Activated Carbon for the Treatment of Heavy Metals and Chlorophenols Contaminated Water. J. Clean. Prod. 2017, 162, 958-972. [CrossRef]

4. Vymazal, J. Horizontal Sub-Surface Flow and Hybrid Constructed Wetlands Systems for Wastewater Treatment. Ecol. Eng. 2005, 25, 478-490. [CrossRef]

5. Lavrnić, S.; Alagna, V.; Iovino, M.; Anconelli, S.; Solimando, D.; Toscano, A. Hydrological and Hydraulic Behaviour of a Surface Flow Constructed Wetland Treating Agricultural Drainage Water in Northern Italy. Sci. Total Environ. 2020, 702, 134795. [CrossRef] [PubMed]

6. Barbagallo, S.; Cirelli, G.L.; Marzo, A.; Milani, M.; Toscano, A. Hydraulic Behaviour and Removal Efficiencies of Two H-SSF Constructed Wetlands for Wastewater Reuse with Different Operational Life. Water Sci. Technol. J. Int. Assoc. Water Pollut. Res. 2011, 64, 1032-1039. [CrossRef] [PubMed]

7. Jucherski, A.; Nastawny, M.; Walczowski, A.; Gajewska, M.; Józ, K. Assessment of the Technological Reliability of a Hybrid Constructed Wetland for Wastewater Treatment in a Mountain Eco-Tourist Farm in Poland. Water Sci. Technol. 2017, 75, 2649-2658. [CrossRef] [PubMed]

8. Lavrnić, S.; Nan, X.; Blasioli, S.; Braschi, I.; Anconelli, S.; Toscano, A. Performance of a Full Scale Constructed Wetland as Ecological Practice for Agricultural Drainage Water Treatment in Northern Italy. Ecol. Eng. 2020, 154, 105927. [CrossRef]

9. Gorgoglione, A.; Torretta, V. Sustainable Management and Successful Application of Constructed Wetlands: A Critical Review. Sustainability 2018, 10, 3910. [CrossRef] 
10. Semeraro, T.; Giannuzzi, C.; Beccarisi, L.; Aretano, R.; De Marco, A.; Pasimeni, M.R.; Zurlini, G.; Petrosillo, I. A Constructed Treatment Wetland as an Opportunity to Enhance Biodiversity and Ecosystem Services. Ecol. Eng. 2015, 82, 517-526. [CrossRef]

11. Zurita, F.; White, J.R. Comparative Study of Three Two-Stage Hybrid Ecological Wastewater Treatment Systems for Producing High Nutrient, Reclaimed Water for Irrigation Reuse in Developing Countries. Water 2014, 6, 213. [CrossRef]

12. Lavrnić, S.; Mancini, M.L. Can Constructed Wetlands Treat Wastewater for Reuse in Agriculture? Review of Guidelines and Examples in South Europe. Water Sci. Technol. J. Int. Assoc. Water Pollut. Res. 2016, 73, 2616-2626. [CrossRef] [PubMed]

13. Milani, M.; Toscano, A. Evapotranspiration from Pilot-Scale Constructed Wetlands Planted with Phragmites Australis in a Mediterranean Environment. J. Environ. Sci. Heal. Part A Toxic Hazardous Subst. Environ. Eng. 2013, 48, 568-580. [CrossRef] [PubMed]

14. Jordán-Cuebas, F.; Krogmann, U.; Asce, M.; Andrews, C.J.; Senick, J.A.; Hewitt, E.L.; Wener, R.E.; Sorensen Allacci, M.; Plotnik, D. Understanding Apartment End-Use Water Consumption in Two Green Residential Multistory Buildings. J. Water Resour. Plan. Manag. 2018, 144. [CrossRef]

15. Guedes-Alonso, R.; Montesdeoca-Esponda, S.; Herrera-Melián, J.A.; Rodríguez-Rodríguez, R.; Ojeda-González, Z.; Landívar-Andrade, V.; Sosa-Ferrera, Z.; Santana-Rodríguez, J.J. Pharmaceutical and Personal Care Product Residues in a Macrophyte Pond-Constructed Wetland Treating Wastewater from a University Campus: Presence, Removal and Ecological Risk Assessment. Sci. Total Environ. 2020, 703, 135596. [CrossRef]

16. Ricart, S. Risk-Yuck Factor Nexus in Reclaimed Wastewater for Irrigation: Comparing Farmers' Attitudes and Public Perception. Water 2019, 11, 187. [CrossRef]

17. Ghermandi, A.; Fichtman, E. Cultural Ecosystem Services of Multifunctional Constructed Treatment Wetlands and Waste Stabilization Ponds: Time to Enter the Mainstream? Ecol. Eng. 2015, 84, 615-623. [CrossRef]

18. Rice, J.; Wutich, A.; White, D.D.; Westerhoff, P. Comparing Actual de Facto Wastewater Reuse and Its Public Acceptability: A Three City Case Study. Sustain. Cities Soc. 2016, 27, 467-474. [CrossRef]

19. Schmid, S.; Bogner, F. What Germany's University Beginners Think about Water Reuse. Water 2018, $10,731$. [CrossRef]

20. Amaral, R.; Ferreira, F.; Galvão, A.; Matos, J.S. Constructed Wetlands for Combined Sewer over Fl Ow Treatment in a Mediterranean Country, Portugal. Water Sci. Technol. 2013, 67, 2739-2745. [CrossRef]

21. Ciria, M.P.; Solano, M.L.; Soriano, P. Role of Macrophyte Typha Latifolia in a Constructed Wetland for Wastewater Treatment and Assessment of Its Potential as a Biomass Fuel. Biosyst. Eng. 2005, 92, 535-544. [CrossRef]

22. Villalobos, R.M.; Zúñiga, J.; Salgado, E.; Cristina, M. Constructed Wetlands for Domestic Wastewater Treatment in a Mediterranean Climate Region in Chile. Electron. J. Biotechnol. 2013, 16, 1-13. [CrossRef]

23. Mancini, B. Application of Sequence Based Typing (SBT) Technique to Typing Strains of Legionella spp.: Development of an Environmental Risk Map; University of Bologna: Bologna, Italy, 2017.

24. Lavrnić, S.; Cristino, S.; Zapater-Pereyra, M.; Vymazal, J.; Cupido, D.; Lucchese, G.; Mancini, B.; Mancini, M.L. Effect of Earthworms and Plants on the Efficiency of Vertical Flow Systems Treating University Wastewater. Environ. Sci. Pollut. Res. 2019, 26, 10354-10362. [CrossRef] [PubMed]

25. APHA. Standard Methods for the Examination of Water and Wastewater, 21st ed.; American Public Health Association: Washington, DC, USA, 2005.

26. ISO. 9308-1 Water Quality-Enumeration of Escherichia Coli and Coliform Bacteria-Part 1: Membrane Filtration Method for Waters with Low Bacterial Background Flora; ISO: Geneva, Switzerland, 2014.

27. ISO. 7899-2 Water Quality—Detection and Enumeration of Intestinal Enterococci_Part 2: Membrane Filtration Method; ISO: Geneva, Switzerland, 2000.

28. Tchobanoglous, G.; Burton, E.C.; Stensel, H.D. Wastewater Engineering: Treatment Disposal and Reuse; Metcalf \& Eddy: Bedford, MA, USA; McGraw-Hill, Inc.: Singapore, 2004.

29. Ávila, C.; García, J.; Garfí, M. Influence of Hydraulic Loading Rate, Simulated Storm Events and Seasonality on the Treatment Performance of an Experimental Three-Stage Hybrid Constructed Wetland System. Ecol. Eng. 2016, 87, 324-332. [CrossRef]

30. Zhai, J.; Xiao, J.; Rahaman, M.H.; John, Y.; Xiao, J. Seasonal Variation of Nutrient Removal in a Full-Scale Artificial Aerated Hybrid Constructed Wetland. Water 2016, 8, 551. [CrossRef] 
31. Kadlec, R.H.; Wallace, S. Treatment Wetlands, 2nd ed.; CRC Press: Boca Raton, FL, USA, 2009.

32. Torrijos, V.; Gonzalo, O.G.; Trueba-Santiso, A.; Ruiz, I.; Soto, M. Effect of By-Pass and Effluent Recirculation on Nitrogen Removal in Hybrid Constructed Wetlands for Domestic and Industrial Wastewater Treatment. Water Res. 2016, 103, 92-100. [CrossRef]

33. Gajewska, M.; Skrzypiec, K.; Jó, K.; Mucha, Z.; Karczmarczyk, A.; Bugajski, P. Kinetics of Pollutants Removal in Vertical and Horizontal Flow Constructed Wetlands in Temperate Climate. Sci. Total Environ. 2020, 718, 137371. [CrossRef]

34. Wojciechowska, E.; Gajewska, M.; Ostojski, A. Reliability of Nitrogen Removal Processes in Multistage Treatment Wetlands Receiving High-Strength Wastewater. Ecol. Eng. 2017, 98, 365-371. [CrossRef]

35. Jóźwiakowski, K.; Bugajski, P.; Kurek, K.; De Fátima, M.; De Carvalho, N.; Adelaide, M.; Almeida, A.; Siwiec, T.; Borowski, G.; Czeka, W.; et al. The Efficiency and Technological Reliability of Biogenic Compounds Removal during Long-Term Operation of a One-Stage Subsurface Horizontal Flow Constructed Wetland. Sep. Purif. Technol. 2018, 202, 216-226. [CrossRef]

36. Reddy, G.B.; Raczkowski, C.W.; Cyrus, J.S.; Szogi, A. Carbon Sequestration in a Surface Fl Ow Constructed Wetland after 12 Years of Swine Wastewater Treatment. Water Sci. Technol. 2016, 73, 2501-2508. [CrossRef]

37. Legislative Decree, n. 152, 03/04/2006, Gazzetta Ufficiale n. 88. Environmental Regulations. Available online: https://www.gazzettaufficiale.it/dettaglio/codici/materiaAmbientale (accessed on 12 August 2020).

38. Legislative Decree, n. 185, 23/07/2003 Gazzetta Ufficiale n. 169. Italian Technical Guidelines for Wastewater Reuse. Available online: http://www.gazzettaufficiale.it/eli/id/2003/07/23/003G0210/sg (accessed on 12 August 2020).

39. European Union. Regulation (EU) 2020/741 of the European Parliament and of the Council of 25 May 2020 on Minimum Requirements for Water Reuse (Text with EEA Relevance); European Union: Brussels, Belgium, 2020.

40. Ávila, C.; Garfí, M.; García, J. Three-Stage Hybrid Constructed Wetland System for Wastewater Treatment and Reuse in Warm Climate Regions. Ecol. Eng. 2013, 61, 43-49. [CrossRef]

41. Wu, S.; Carvalho, P.N.; Müller, J.A.; Manoj, V.R.; Dong, R. Sanitation in Constructed Wetlands: A Review on the Removal of Human Pathogens and Fecal Indicators. Sci. Total Environ. 2016, 541, 8-22. [CrossRef]

42. Toscano, A.; Hellio, C.; Marzo, A.; Milani, M.; Lebret, K.; Cirelli, G.L.; Langergraber, G. Removal Efficiency of a Constructed Wetland Combined with Ultrasound and UV Devices for Wastewater Reuse in Agriculture. Environ. Technol. 2013, 34, 2327-2336. [CrossRef] [PubMed]

43. Raboni, M.; Gavasci, R.; Urbini, G. UASB Followed by Sub-Surface Horizontal Flow Phytodepuration for the Treatment of the Sewage Generated by a Small Rural Community. Sustainability 2014, 6, 6998-7012. [CrossRef]

44. Zapater-Pereyra, M.; Lavrnić, S.; van Dien, F.; van Bruggen, J.J.A.; Lens, P.N.L. Constructed Wetroofs: A Novel Approach for the Treatment and Reuse of Domestic Wastewater. Ecol. Eng. 2016, 94, 545-554. [CrossRef]

45. Melián, J.A.H.; Rodríguez, A.J.M.; Araña, J.; Díaz, O.G.; Henríquez, J.J.G. Hybrid Constructed Wetlands for Wastewater Treatment and Reuse in the Canary Islands. Ecol. Eng. 2010, 36, 891-899. [CrossRef]

46. Collison, R.S.; Grismer, M.E. Nitrogen and COD Removal from Septic Tank Wastewater in Subsurface Flow Constructed Wetlands: Plants Effects. Water Environ. Res. Res. Publ. Water Environ. Fed. 2015, 87, 1999-2007. [CrossRef]

47. Carballeira, T.; Ruiz, I.; Soto, M. Effect of Plants and Surface Loading Rate on the Treatment Efficiency of Shallow Subsurface Constructed Wetlands. Ecol. Eng. 2016, 90, 203-214. [CrossRef]

48. Headley, T.; Nivala, J.; Kassa, K.; Olsson, L.; Wallace, S.; Brix, H.; van Afferden, M.; Müller, R. Escherichia Coli Removal and Internal Dynamics in Subsurface Flow Ecotechnologies: Effects of Design and Plants. Ecol. Eng. 2013, 61, 564-574. [CrossRef]

49. Nivala, J.; Wallace, S.; Headley, T.; Kassa, K.; Brix, H.; van Afferden, M.; Müller, R. Oxygen Transfer and Consumption in Subsurface Flow Treatment Wetlands. Ecol. Eng. 2013, 61, 544-554. [CrossRef]

50. Leto, C.; Tuttolomondo, T.; La Bella, S.; Leone, R.; Licata, M. Effects of Plant Species in a Horizontal Subsurface Flow Constructed Wetland-Phytoremediation of Treated Urban Wastewater with Cyperus alternifolius, L. and Typha latifolia, L. in the West of Sicily (Italy). Ecol. Eng. 2013, 61, 282-291. [CrossRef]

51. Kasprzyk, M.; Pierzgalski, K.; Wojciechowska, E.; Obarska-pempkowiak, H.; Gajewska, M. Application of Eco-Innovative Technologies of Nutrients Removal in Wastewater-Case Study BARITECH Project. Rocz. Ochr. Sr. 2017, 19, 143-160. 
52. Chen, Y.; Wen, Y.; Zhou, Q.; Huang, J.; Vymazal, J.; Kuschk, P. Sulfate Removal and Sulfur Transformation in Constructed Wetlands: The Roles of Filling Material and Plant Biomass. Water Res. 2016, 102, 572-581. [CrossRef] [PubMed]

53. Fountoulakis, M.S.; Daskalakis, G.; Papadaki, A.; Kalogerakis, N.; Manios, T. Use of Halophytes in Pilot-Scale Horizontal Flow Constructed Wetland Treating Domestic Wastewater. Environ. Sci. Pollut. Res. 2017, 24, 16682-16689. [CrossRef]

54. Tian, T.; Tam, N.F.Y.; Zan, Q.; Cheung, S.G.; Shin, P.K.S.; Wong, Y.S.; Zhang, L.; Chen, Z. Performance and Bacterial Community Structure of a 10-Years Old Constructed Mangrove Wetland. Mar. Pollut. Bull. 2017, 124, 1096-1105. [CrossRef]

55. Arroyo, P.; Blanco, I.; Cortijo, R. Twelve-Year Performance of a Constructed Wetland for Municipal Wastewater Treatment: Water Quality Improvement, Metal Distribution in Wastewater, Sediments, and Vegetation. Water Air Soil Pollut. 2013, 224. [CrossRef]

56. Garcia-Cuerva, L.; Berglund, E.Z.; Binder, A.R. Public Perceptions of Water Shortages, Conservation Behaviors, and Support for Water Reuse in the U.S. Resour. Conserv. Recycl. 2016, 113, 106-115. [CrossRef]

57. Zhang, C.; Wen, L.; Wang, Y.; Liu, C.; Zhou, Y.; Lei, G. Can Constructed Wetlands Be Wildlife Refuges? A Review of Their Potential Biodiversity Conservation Value. Sustainability 2020, 12, 1442. [CrossRef]

58. Ezeah, C.; Reyes, C.A.R.; Gutiérrez, J.F. Constructed Wetland Systems as a Methodology for the Treatment of Wastewater in Bucaramanga Industrial Park. J. Geosci. Environ. Prot. 2015, 3, 1-14. [CrossRef]

59. Everard, M.; Harrington, R.; McInnes, R.J. Facilitating Implementation of Landscape-Scale Water Management: The Integrated Constructed Wetland Concept. Ecosyst. Serv. 2012, 2, 27-37. [CrossRef]

Publisher's Note: MDPI stays neutral with regard to jurisdictional claims in published maps and institutional affiliations. 